\title{
Larangan Begadang sebagai Pemeliharaan Imunitas Perspektif Islam
}

\author{
Nurip Almunawir \\ Jurusan Ilmu Al-Quran dan Tafsir, Fakultas Ushuluddin, \\ UIN Sunan Gunung Djati Bandung \\ nurip_almunawir@yahoo.co.id
}

\begin{abstract}
This study intends to analyze the hadith about the prohibition of staying up late as immunity maintenance. This study uses a qualitative approach that emphasizes literature study through the takhrij and syarah hadith methods by applying contemporary analysis in the medical field. The results of the research and discussion show that the hadith regarding the prohibition of staying up late is of authentic quality based on the takhrij review so that it can be accepted as an Islamic argument. As for the syarah of this hadith, it shows that staying up late is a behavior that the Messenger of Allah hated, the attitude of the Apostle can be understood, that he forbade his people to stay up late, while this prohibition is only makruh and not haram. The conclusion in this study is that the hadith narrated by Imam Ahmad no. 18945 is maqbul for efforts to increase immunity by prohibiting staying up late.
\end{abstract}

Keywords: Hadith, Immunity, Medical

\begin{abstract}
Abstrak
Penelitian ini bermaksud untuk menganalisis hadits tentang larangan begadang sebagai pemeliharaan imunitas. Penelitian ini menggunakan pendekatan kualitatif yang ditekankan pada studi pustaka melalui metode takhrij dan syarah hadits dengan menerapkan analisis kontemporer pada bidang medis. Hasil penelitian dan pembahasan menunjukkan bahwa hadits tentang larangan begadang berkualitas shahih berdasarkan tinjauan takhrij sehingga dapat diterima untuk dijadikan dalil Islam. Adapun syarah hadits ini menunjukkan bahwa begadang adalah perilaku yang sangat dibenci oleh Rasulullah sikap Rasul tersebut dapat dipahami, bahwa beliau melarang umatnya untuk begadang, adapun larangan ini hanya sebatas makruh dan bukan haram. Kesimpulan dalam penelitian ini adalah bahwa hadits riwayat Imam Ahmad No. 18945 ini maqbul bagi upaya peningkatan imunitas dengan dilarangnya begadang.
\end{abstract}


Jurnal Riset Agama, Volume 1, Nomor 1 (April 2021): 71-82

Nurip Almunawir/Larangan Begadang sebagai Pemeliharaan Imunitas Perspektif Islam

Kata Kunci: Hadits, Imunitas, Medis

\section{Pendahuluan}

Begadang merupakan kebiasaan terjaga hingga larut malam dan orang yang begadang biasanya akan tidur di saat pagi datang (Kuntoro, 2018). Begadang bagi masyarakat Indonesia sudah menjadi hal yang lumrah (Kuntoro, 2018). Kebanyakan begadang dilakukan oleh karyawan yang bekerja pada shift malam dan mahasiswa yang mengerjakan banyak tugas dengan waktu deadline yang singkat (Purnama, 2021). Di sisi lain begadang ternyata sudah menjadi kebiasaan bagi sebagian masyarakat terutama anak muda untuk melakukan hal-hal yang tidak penting, seperti bermain game online, memainkan gitar, dan sebagainya (Purnama, 2021). Begadang karena alasan yang logis dengan sebab beberapa kepentingan yang harus diselesaikan, tentu itu menjadi hal yang wajar dan dapat diterima. Namun, jika begadang dilakukan karena hal yang kurang bermanfaat, maka hal ini perlu kita perbaiki. Terutama saat ini kita masih berada di tengah pandemi Covid-19 maka menjaga imunitas tubuh tentu menjadi hal yang sangat penting (Mustofa \& Suhartatik, 2020). Oleh karena itu, meninjau dari fenomena begadang tersebut penulis tertarik untuk mengetahui lebih dalam mengenai dampak negatif dari begadang dan bagaimana cara menghilangkan kebiasaan begadang menggunakan teori ilmu hadits berikut syarah-nya melalui pendekatan ilmu medis.

Sejumlah ahli telah melakukan penelitian mengenai begadang sebagaimana dalam tinjauan pustaka ini. Di antaranya Purnama, Mohammad Dida Wildan (2021), "Negative Impact of Staying Up Late for Health," Jurnal Studi Keperawatan. Penelitian ini membahas tentang apa saja dampak negatif dari begadang sekaligus untuk mengetahui seberapa besar wawasan masyarakat tentang dampak begadang, cara menghilangkan kebiasaan begadang dan hal-hal yang perlu dipersiapkan di saat begadang. Penelitian ini menggunakan metode kuantitatif dengan teknik pengolahan data kuesioner melalui google form yang berisi pertanyaan tentang dampak negatif dari begadang yang dirasakan oleh responden, cara mengatasinya dan hal-hal yang harus dipersiapkan ketika akan begadang. Hasil dari penelitian ini menunjukkan bahwa responden merasakan langsung dampak negatif pada tubuh ketika mereka selesai begadang, mereka juga tahu bagaimana cara mengatasi kebiasaan begadang, namun sayangnya banyak dari mereka yang tidak tahu hal apa yang harus dipersiapkan ketika ingin melakukannya. Maka dari penelitian ini dapat disimpulkan bahwa kebiasaan begadang menjadi hal yang lumrah bagi sebagian besar responden, dan banyak dari mereka langsung merasakan dampak negatif dari begadang (Purnama, 2021). Eliasson, A. H., 
Jurnal Riset Agama, Volume 1, Nomor 1 (April 2021): 71-82

Nurip Almunawir/Larangan Begadang sebagai Pemeliharaan Imunitas Perspektif Islam

Lettieri, C. J., \& Eliasson, A. H. (2010), “Early to Bed, Early to Rise! Sleep Habits and Academic Performance in College Students," Sleep Breath. Penelitian ini menyelidiki tentang kepentingan relatif dari total waktu tidur yang dibandingkan dengan lamanya waktu tidur dan waktu terjaga untuk kinerja akademik. Penelitian ini menggunakan metode survei berbasis kuesioner mahasiswa pada bulan Oktober 2007. Kuis yang berisi mengenai informasi rinci kebiasaan tidur termasuk: tidur siang, alasan kurang tidur, prestasi akademik, kebiasaan belajar, waktu yang dihabiskan untuk bekerja di luar sekolah, dan penggunaan stimulan. Hasil dari penelitian ini menunjukkan bahwa siswa dengan kinerja tertinggi memiliki waktu tidur lebih awal secara signifikan $(p=0,05)$ dan waktu terjaga $(p=0,008)$. Tidur siang cenderung lebih umum di antara mereka yang berkinerja tinggi $(p=0.07)$. Yang terpenting, tidak ada perbedaan yang signifikan dalam total waktu tidur dengan atau tanpa tidur siang, kebiasaan tidur akhir pekan, waktu belajar, jenis kelamin, ras, alasan begadang, atau penggunaan minuman berkafein, pil stimulan yang dijual bebas, atau penggunaan resep stimulan. Maka dari penelitian ini dapat disimpulkan bahwa waktu tidur dan terjaga berkorelasi lebih erat daripada total waktu tidur dan faktor relevan lainnya. Temuan ini memiliki implikasi penting untuk program yang dimaksudkan untuk meningkatkan kinerja akademik dengan menargetkan kebiasaan tidur siswa (Eliasson et al., 2010). Herwanto, \& Umboh, A. (2017), "Penurunan Kapasitas Memori Kerja pada Residen Pediatri yang Kurang Tidur," Jurnal Muara Sains, Teknologi, Kedokteran, dan Ilmu Kesehatan. Penelitian ini membahas tentang adanya penurunan memori kerja yang terjadi pada residen pediatri yang kurang tidur. Metode penelitian yang digunakan adalah potong-lintang, deskriptif-analitik yang dilakukan di Departemen Ilmu Kesehatan Anak Fakultas Kedokteran Universitas Sam Ratulangi pada periode Januari-Februari 2014 terhadap residen yang masih terdaftar di dalam program Program Pendidikan Dokter Sepesialis Ilmu Kesehatan Anak (PPDS IKA). Hasil dari penelitian ini adalah didapatkan hubungan yang signifikan terkait penurunan kapasitas memori kerja pada residen setelah tugas jaga malam $(r=0,776$, $p<0,001)$. Dari penelitian ini dapat disimpulkan yakni tugas jaga malam menurunkan waktu tidur dan mempengaruhi kapasitas memori kerja. Penurunan kapasitas memori kerja dapat menjelaskan adanya suatu gangguan pengambilan keputusan selama terjadi kekurangan tidur (Herwanto \& Umboh, 2017).

Penelitian sebelumnya mengenai begadang atau kurangnya tidur yang telah diuraikan pada tinjauan pustaka sangat membantu terhadap penyusunan kerangka berpikir ini. Fenomena begadang sudah menjadi suatu kebiasaan umum bagi masyarakat terutama mereka yang berprofesi sebagai karyawan dan juga mahasiswa (Purnama, 2021). Banyaknya tugas mengharuskan mereka untuk tetap bekerja, hal inilah yang menjadi salah 
Jurnal Riset Agama, Volume 1, Nomor 1 (April 2021): 71-82

Nurip Almunawir/Larangan Begadang sebagai Pemeliharaan Imunitas Perspektif Islam

satu alasan utama mereka begadang sehingga membuat jam tidur tidak teratur (Purnama, 2021). Orang yang kekurangan jam tidur akan berdampak buruk pada kesehatannya seperti penurunan kapasitas memori kerja, meningkatnya kadar gula darah, depresi, stress, penyakit jantung, dan struk (Arieselia et al., 2014; Herwanto \& Umboh, 2017; Yogis et al., 2017). Tentu hal ini semua akan membuat imunitas tubuh menurun. Imunitas tubuh adalah sistem kekebalan tubuh yang berfungsi untuk melawan benda asing baik itu bakteri, virus maupun mikrorganisme yang masuk ke dalam tubuh yang dapat mengganggu kesehatan (Sumarmi, 2020). Meningkatkan imunitas tubuh di masa pandemi Covid-19 tentulah sangat penting sebagai suatu upaya untuk menjaga diri agar tidak tertular Covid-19. Beberapa cara yang bisa dilakukan untuk dapat meningkatkan imunitas tubuh di antaranya dengan menjaga pola makan yang sehat, olahraga secara teratur dan merubah pola hidup menjadi lebih baik (Mustofa \& Suhartatik, 2020). Salah satu pola hidup yang baik adalah dengan menghindari begadang di malam hari. Hadits adalah segala apapun yang berasal dari Nabi shallallaahu 'alaihi wasallam (Darmalaksana \& Qomaruzzaman, 2020). Hadits merupakan sumber hukum Islam kedua setelah Al-Quran yang memiliki peranan penting dalam Islam (Ridwan et al., 2021). Takhrij adalah suatu metode untuk mengeluarkan hadits dari kitab hadits untuk dilakukan penelitian terhadap kualitas ke-shahih-annya yang mencakup shahih, hasan, dan dha'if (Darmalaksana, 2021a). Syarah adalah penjelasan mengenai hadits, adapun syarah yang berkaitan dengan hadits adalah usaha menafsirkan makna yang berada di balik teks hadits (Darmalaksana, 2020c). Berdasarkan pencarian terhadap hadits yang ada kaitannya dengan begadang melalui aplikasi Ensiklopedia Hadits Kitab 9 Imam ditemukan beberapa hadits, akan tetapi hadits yang akan penulis bahas pada penelitian ini hanyalah hadits riwayat Imam Ahmad No. 18945 Kitab Musnad Penduduk Bashrah Bab Hadits Abu Barzah Al-Aslami radhiyallahu ta'ala 'anhu (Saltanera, 2015). Penulis akan melakukan takhrij terhadap hadits tersebut. Setelah status keshahihan hadits diketahui selanjutnya dilakukan syarah untuk menjelaskan makna yang terkandung dalam teks hadits (Darmalaksana, 2021a). Oleh karena itu, penelitian ini akan membahas "Hadits tentang begadang" melalui metode takhrij dan syarah menggunakan pendekatan ilmu yang sejalan dan relevan dengannya.

Berdasar pada pemaparan di atas, penulis berupaya untuk menyusun formula penelitian yang terdiri dari rumusan masalah penelitian, pertanyaan utama terkait penelitian, dan tujuan penelitian (Darmalaksana, 2020a). Rumusan masalah dalam penelitian ini adalah terdapat syarah hadits terkait larangan begadang sebagai pemeliharaan imunitas. Pertanyaan utama penelitian ini adalah bagaimana syarah hadits terkait larangan begadang sebagai pemeliharaan imunitas. Adapun pertanyaan penelitian 
Jurnal Riset Agama, Volume 1, Nomor 1 (April 2021): 71-82

Nurip Almunawir/Larangan Begadang sebagai Pemeliharaan Imunitas Perspektif Islam

secara terperinci yakni bagaimana teks hadits tentang larangan begadang, bagaimana kualitas hadits tentang larangan begadang, dan bagaimana syarah hadits tentang larangan begadang sebagai pemeliharaan imunitas. Tujuan penelitian ini yaitu membahas syarah hadits terkait larangan begadang sebagai pemeliharaan imunitas. Dengan dilakukannya penelitian ini diharapkan dapat memberikan pencerahan kepada masyarakat akan pentingnya menghindari aktivitas begadang.

\section{Metode Penelitian}

Penelitian ini menggunakan pendekatan kualitatif yang ditekankan pada studi pustaka, dengan kata lain peneliti tidak turun langsung ke lapangan (Darmalaksana, 2020b). Penelitian ini menggunakan metode takhrij dan syarah (Darmalaksana, 2020d) terhadap hadits tentang begadang melalui analisis kontemporer (Darmalaksana, 2020c).

\section{Hasil dan Pembahasan}

Hasil penelitian dan pembahasan disajikan dalam beberapa hal berikut ini.

\section{Teks Hadits Begadang}

Berdasarkan pencarian hadits tentang begadang melalui aplikasi Ensiklopedia Hadits Kitab 9 Imam (Saltanera, 2015), penulis mendapati beberapa hadits, akan tetapi hadits yang akan menjadi pembahasan utama dalam penelitian ini adalah hadits riwayat Ahmad No. 18945 Kitab Musnad Penduduk Bashrah Bab Hadits Abu Barzah al-Aslami radhiyallahu ta'ala 'anhu, sebagai berikut.

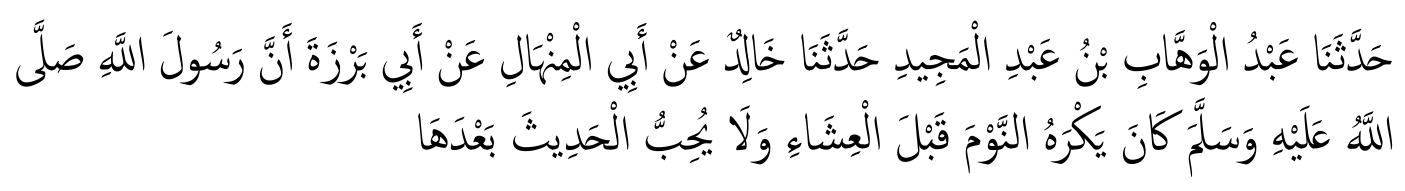

Artinya: Telah menceritakan kepada kami [Abdul Wahhab bin Abdul Majid] telah menceritakan kepada kami [Khalid] dari [Abu Minhal] dari [Abu Barzah] bahwa sesungguhnya Rasulullah membenci tidur sebelum shalat Isya dan tidak menyukai berkata-kata (ngobrol, ngerumpi) setelahnya (setelah Isya) [H.R. Imam Ahmad].

\section{Takhrij Hadits Begadang} berikut.

Takhrij hadits terkait begadang ditampilkan dalam bentuk tabel

\section{Tabel 1. Daftar Rawi Sanad}


Jurnal Riset Agama, Volume 1, Nomor 1 (April 2021): 71-82

Nurip Almunawir/Larangan Begadang sebagai Pemeliharaan Imunitas Perspektif Islam

\begin{tabular}{|c|c|c|c|c|c|c|c|c|}
\hline \multirow[t]{2}{*}{ No. } & \multirow{2}{*}{$\begin{array}{l}\text { Rawi } \\
\text { Sanad }\end{array}$} & \multicolumn{2}{|c|}{$\begin{array}{l}\text { Lahir/ } \\
\text { Wafat }\end{array}$} & \multirow[t]{2}{*}{ Negeri } & \multirow[t]{2}{*}{ Kuniyah } & \multicolumn{2}{|r|}{$\begin{array}{c}\text { Komentar } \\
\text { Ulama }\end{array}$} & \multirow[t]{2}{*}{ Kalangan } \\
\hline & & L & W & & & - & + & \\
\hline 1. & $\begin{array}{l}\text { Nadlah } \\
\text { bin } \\
\text { ‘Ubaid }\end{array}$ & & $\begin{array}{l}64 \\
\mathrm{H}\end{array}$ & Bashrah & Abu Barzah & & & Sahabat \\
\hline 2. & $\begin{array}{l}\text { Sayyar } \\
\text { bin } \\
\text { Salaama } \\
\text { h }\end{array}$ & & $\begin{array}{l}129 \\
\mathrm{H}\end{array}$ & Bashrah & $\begin{array}{l}\text { Abu al- } \\
\text { Minhal }\end{array}$ & & $\begin{array}{l}\text { - Abu } \\
\text { Hatim: } \\
\text { Shaduuq } \\
\text { shalih } \\
\text { - Yahya bin } \\
\text { Ma'in: } \\
\text { Tsiqah } \\
\text { - An-Nasa'i: } \\
\text { Tsiqah } \\
\text { - Al-'Ajli: } \\
\text { Tsiqah } \\
\text { - Ibnu Sa'd: } \\
\text { Tsiqah } \\
\text { - Ibnu } \\
\text { Hibban: } \\
\text { Disebutkan } \\
\text { dalam 'ats } \\
\text { tsigaat } \\
\text { - Ibnu Hajar } \\
\text { al- } \\
\text { Atsqalani: } \\
\text { tsigah }\end{array}$ & $\begin{array}{l}\text { Tabi'in } \\
\text { kalangan } \\
\text { biasa }\end{array}$ \\
\hline 3. & $\begin{array}{l}\text { Khalid } \\
\text { bin } \\
\text { Mihran }\end{array}$ & & $\begin{array}{l}141 \\
\mathrm{H}\end{array}$ & Bashrah & $\begin{array}{l}\text { Abu al- } \\
\text { Manazil }\end{array}$ & & $\begin{array}{l}\text { - Ahmad bin } \\
\text { Hanbal: } \\
\text { Tsabat } \\
\text { - An-Nasa'i: } \\
\text { Tsiqah } \\
\text { - Ibnu } \\
\text { Hibban: } \\
\text { Disebutkan } \\
\text { dalam 'ats } \\
\text { tsiqaat } \\
\text { - Al-'Ajli: } \\
\text { Bashari } \\
\text { tsigah } \\
\text { - Adz- } \\
\text { Dzahabi: } \\
\text { al-Hafidz } \\
\text { tsiqah imam } \\
\text { - Ibnu Hajar } \\
\text { al- } \\
\text { Atsqalani: } \\
\text { Tsiqah } \\
\text { yursil }\end{array}$ & $\begin{array}{l}\text { Tabi'in } \\
\text { kalangan } \\
\text { biasa }\end{array}$ \\
\hline
\end{tabular}


Jurnal Riset Agama, Volume 1, Nomor 1 (April 2021): 71-82

Nurip Almunawir/Larangan Begadang sebagai Pemeliharaan Imunitas Perspektif Islam

\begin{tabular}{|c|c|c|c|c|c|c|c|}
\hline 4. & $\begin{array}{l}\text { Abdul } \\
\text { Wahhab } \\
\text { bin } \\
\text { 'Abdul } \\
\text { Majid } \\
\text { bin Ash } \\
\text { Shalti }\end{array}$ & & $\begin{array}{l}194 \\
\mathrm{H}\end{array}$ & Bashrah & $\begin{array}{l}\text { Abu } \\
\text { Muhammad }\end{array}$ & $\begin{array}{l}\text { - Ibnu } \\
\text { Hibban: } \\
\text { Disebutkan } \\
\text { dalam 'ats } \\
\text { tsiqaat } \\
\text { - Al-'Ajli: } \\
\text { Tsiqah } \\
\text { - Ibnu Hajar: } \\
\text { Tsiqah } \\
\text { - Adz- } \\
\text { Dzahabi: } \\
\text { Hafidz } \\
\end{array}$ & $\begin{array}{l}\text { Tabi'ut } \\
\text { Tabi'in } \\
\text { kalangan } \\
\text { pertengahan }\end{array}$ \\
\hline 5. & $\begin{array}{l}\text { Imam } \\
\text { Ahmad } \\
\text { bin } \\
\text { Muham } \\
\text { ad bin } \\
\text { Hanbal }\end{array}$ & $\begin{array}{l}164 \\
\mathrm{H}\end{array}$ & $\begin{array}{l}241 \\
\mathrm{H}\end{array}$ & Baghdad & $\begin{array}{l}\text { Abu } \\
\text { Abdillah }\end{array}$ & Imam Hadits & Mudawwin \\
\hline
\end{tabular}

Tabel 1 merupakan daftar rawi dan sanad hadits riwayat Imam Ahmad No. 18945 terkait begadang. Hadits ini diriwayatkan oleh 5 (lima) orang rawi berawal dari sahabat sampai mudawwin. Sebanyak 4 (empat) orang rawi tidak dikatehui tahun lahirnya, yaitu Nadlah bin 'Ubaid, Sayyar bin Salaamah, Khalid bin Mihran, dan Abdul Wahhab bin Abdul Majid. Menurut ilmu hadits, rawi pertama (Nadlah bin 'Ubaid) adalah sanad terakhir sedangkan rawi terakhir (Imam Ahmad) adalah sanad pertama (Darmalaksana, 2021b).

\section{Kualitas Hadits Begadang}

Hadits menjadi shahih bila memenuhi syarat: 1) sanadnya harus bersambung; 2) rawi harus adil dan dhabit (kuat hafalannya); dan 3) matan hadits tidak ada syadz (janggal) dan tidak ada 'illat (cacat) (Darmalaksana, 2018). Pada tabel 1 tampak banyak para ulama yang memberi komentar positif ( $\left.t a^{\prime} d i l\right)$ terhadap para rawi dengan rata-rata memberi komentar tsiqah. Tsiqah merupakan gabungan dari sifat adil dan dhabith (Nadhiran, 2014). Rawi yang dinilai tsigah berarti ia adalah orang terpercaya dari segi adil dan dhabith (kuat hafalannya). Selain tsiqah para ulama juga memberikan komentar shuduuq shalih, tsabat, dan al-hafidz. Dan juga terlihat jelas pada tabel 1 tidak ada satu pun komentar negatif terhadap para rawi. Dengan demikian, dapat disimpulkan bahwa semua rawi dalam jalur sanad ini seluruhnya adil dan dhabit sehingga dapat mempengaruhi kualitas hadits.

Persambungan sanad oleh para ulama dijadikan salah satu tolak ukur ke-shahih-an suatu hadits (Anshori, 2016). Syarat sanad hadits bersambung adalah adanya guru yang menyampaikan hadits dan murid yang menerima hadits saling bertemu (liqa') yakni guru dan murid hidup sezaman atau satu profesi sebagai muhaditsin (Darmalaksana, 2018, 2020d, 2021a). Apabilla para rawi tidak diketahui tahun lahir dan wafatnya, maka bisa diasumsikan 
Jurnal Riset Agama, Volume 1, Nomor 1 (April 2021): 71-82

Nurip Almunawir/Larangan Begadang sebagai Pemeliharaan Imunitas Perspektif Islam

bahwa rata-rata usia mereka kurang lebih 90 tahun (Darmalaksana, 2018, 2021a). Berdasar pada kaidah tersebut, meski pada tabel 1 ada beberapa rawi yang tidak diketahui tahun lahirnya, maka dapat diperkirakan bahwasannya para rawi saling bertemu di saat meriwayatkan hadits. Selain itu, dapat menjadi bahan pertimbangan juga yakni dengan meninjau dari aspek negerinya yang sama atau berdekatan dan juga tahun wafat para rawi yang tidak begitu jauh masanya. Sehingga dapat disimpulkan bahwa sanad pada hadits riwayat Imam Ahmad No. 18945 bersambung dalam istilah lain ittishalus-sanad (Anshori, 2016).

Di samping penilaian dari segi rawi dan sanad, kualitas hadits ditentukan dari segi matan-nya dengan syarat terhindar dari syudzudz (kejanggalan) dan terlepas dari 'illat (cacat) (Devi, 2020). Dari segi matan teks hadits tentang begadang tidak terdapat syadz dalam arti tidak bertentangan dengan akal yang sehat, tidak bertentangan dengan hukum Al-Quran dan hadits lainnya yang lebih tinggi derajatnya, dan tidak bertentangan dengan amalan yang telah disepakati ulama masa lalu (Devi, 2020). Serta tidak ditemukannya 'illat (cacat). Dengan demikian, berdasar pada penjelasan yang telah dipaparkan maka dapat disimpulkan bahwa hadits riwayat Imam Ahmad No. 18945 dapat diterima sebagai hadits shahih.

\section{Syarah Hadits Begadang}

Syarah adalah penjelasan mengenai hadits, adapun syarah yang berkaitan dengan hadits adalah usaha menafsirkan makna yang berada di balik teks hadits (Darmalaksana, 2020c). Hadits yang diterima (maqbul) melalui takhrij maka dapat diamalkan ( $\left.m a^{\prime} m u l\right)$ (Darmalaksana, 2018, 2020d). Berdasarkan takhrij didapati status hadits riwayat Imam Ahmad No. 18945 berkualitas shahih baik dari segi bersambungnya sanad, adil dan dhabit-nya rawi, serta dari segi matan tidak ditemukannya syadz dan 'illat.

Syarah hadits dapat dilakukan dengan berbagai pendekatan, salah satunya melalui pendekatan kontekstual (Darmalaksana, 2021a). Hadits riwayat Imam Ahmad No. 18945 memberikan keterangan bahwasannya Rasulullah membenci orang yang tidur sebelum melaksanakan shalat isya dan tidak menyukai bercakap-cakap setelah melaksanakan shalat isya. Redaksi hadits riwayat Imam Ahmad No. 18945 ini tampak senada dengan hadits riwayat Imam Bukhari No. 514, 535, 564, 729, Imam Muslim No. 1024, dan Imam an-Nas'i No. 491 (Saltanera, 2015). Semua matan (redaksi) hadits ini memiliki sedikit perbedaan. Namun, perbedaan ini tidak memalingkan makna kandungan teks hadits. Bahkan saling menguatkan satu sama lain.

Ibn Hajar al-'Asqalani dalam men-syarah-i kitab shahih bukhari terkait hadits begadang, menjelaskan bahwa kata berbincang-bincang yang dimaksud dalam hadits adalah berbincang-bincang terkait hal yang mubah. Adapun bercakap-cakap tentang hal yang haram, sudah pasti diharamkan 
Jurnal Riset Agama, Volume 1, Nomor 1 (April 2021): 71-82

Nurip Almunawir/Larangan Begadang sebagai Pemeliharaan Imunitas Perspektif Islam

و الْحَدِيتَ بَعْدَهَا Adapan pun juga (Al-'Asqalani, 2005). Adapun terkait kalimah beliau menjelaskan bahwa jika seseorang berbincang-bincang setelah melaksanakan shalat isya memiliki potensi akan meninggalkan shalat malam dan bahkan shalat shubuh karena ketiduran sehingga Rasulullah membenci hal tersebut (Al-'Asqalani, 2005). Berdasar pada penjelasan tersebut maka dapat kita pahami juga terkait kalimat hadits riwayat Imam

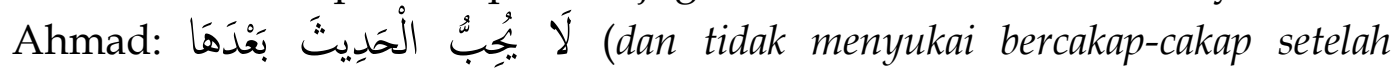
(melaksanakan) isya) juga berisi tentang hal yang sama dengan yang dijelaskan oleh Ibn Hajar al-'Asqalani. Sifat perbincangan akan menarik yang satu pada yang lainnya, akibatnya waktu tidur pun akan tenggelam dan shubuh pun akan tertinggal. Dari sini dapat dipahami makna tersirat

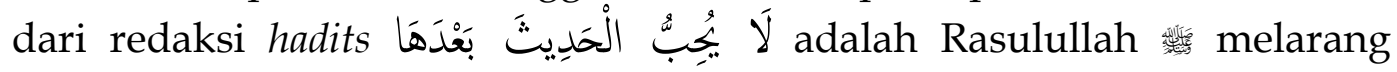
umatnya begadang.

Larangan begadang ini tidak sampai kepada hukum haram, tetapi hanya makruh sebab tuntutan meninggalkan perbuatan ini tidak secara tegas dan pasti (Fuad, 2020) seperti adanya ancaman dosa atau neraka jika mengerjakannya. Selain itu, berdasarkan hadits riwayat Imam Ahmad No. 170 diceritakan bahwasannya Rasulullah 維 juga pernah begadang bersama sahabat Abu Bakar radhiyallahu ta'ala 'anhu dan Umar bin Khattab radhiyallahu ta'ala 'anhu ketika itu beliau mendiskusikan urusan kaum muslimin (Saltanera, 2015). Namun, dalam kondisi normal beliau senantiasa langsung tidur tatkala selesai melaksanakan shalat isya. Oleh karena itu, maka dapat dipahami bahwa hukum begadang itu relatif, hukumnya dapat mubah jika dilakukan untuk kemaslahatan bersama, dapat menjadi haram jika dalam hal maksiat kepada Allah Subhanahu wa Ta'ala seperti judi, dan lainnya dan bisa makruh jika begadang untuk melakukan hal yang tidak penting seperti bermain game online, menonton film, dan lainnya. Adapun hukum asal begadang adalah makruh/dibenci oleh Rasulullah 数.

Begadang yang sudah menjadi kebiasaan akan berdampak negatif terhadap tubuh, adapun beberapa dampak negatif terhadap tubuh dari kebiasaan begadang di antaranya: tubuh akan mengalami lemas, letih, kepala pusing, kantung mata menghitam, badan menjadi pegal-pegal, meningkatnya rasa lapar yang akan mempengaruhi obesitas, meningkatnya kadar gula darah dalam tubuh, dan menurunnya kapasitas memori kerja (Arieselia et al., 2014; Herwanto \& Umboh, 2017; Purnama, 2021; Reza et al., 2019). Orang yang begadang akan tidur di saat pagi datang, di mana semua orang beraktivitas sehingga membuat lingkungan menjadi berisik dan gaduh hingga akhirnya tidur menjadi terganggu dan kualitas tidur pun menjadi buruk. Berdasarkan penelitian, pikiran dan 
Jurnal Riset Agama, Volume 1, Nomor 1 (April 2021): 71-82

Nurip Almunawir/Larangan Begadang sebagai Pemeliharaan Imunitas Perspektif Islam

tubuh orang yang tidur akan menjadi rileks ketika ia tidur di lingkungan yang tenang sehingga membuat kualitas tidurnya baik (Rahmawati et al., 2021). Adapun waktu suasana lingkungan paling tenang adalah di malam hari. Dari paparan tersebut jelas bahwa begadang sangat berakibat buruk terhadap tubuh, pola tidur terganggu, pola makan menjadi rusak, hingga pola hidup pun menjadi tidak sehat yang akibatnya membuat imunitas tubuh menurun. Oleh karena itu, penting bagi kita untuk menghindari begadang agar pola hidup sehat dapat terjaga sehingga imunitas tubuh meningkat.

Setelah mengetahui berbagai dampak buruk akibat begadang, maka jika kita ingin hidup sehat dan imun tubuh tetatp terjaga, terutama di tengah pandemi Covid-19 ini, sebaiknya kita harus menghindari kegiatan begadang. Adapun bagi yang sudah terbiasa begadang, tentu tidak baik jika terus dibiarkan. Oleh karena itu ada beberapa cara yang dapat dilakukan untuk menghilangkan kebiasaan begadang di antaranya: hindari minuman ber-kafein seperti kopi dan teh, jangan tidur siang terlalu lama, tenangkan pikiran sebelum tidur, jauhkan hal-hal yang dapat mengganggu tidur seperti gawai, sejukkan suhu kamar, matikan lampu, selesaikan tugas sekolah, kuliah, ataupun kantor di siang hari dan hindari obrolan apa pun dengan teman di saat mendekati jam tidur (Adzani, 2021; Sulistiyani, 2012).

\section{Kesimpulan}

Hasil temuan yang didapat dalam penelitian ini adalah bahwa hadits tentang begadang berkualitas shahih berdasarkan tinjauan takhrij. Adapun syarah hadits ini menunjukkan bahwa begadang adalah perilaku yang sangat dibenci oleh Rasulullah sikap Rasul tersebut dapat dipahami, bahwa beliau melarang umatnya untuk begadang, adapun larangan ini hanya sebatas makruh dan bukan haram. Berdasarkan penelitian, begadang memiliki banyak sekali dampak negatif yang dapat mengakibatkan imunitas tubuh menurun. Sebagai natijah dari penelitian ini, dapat disimpulkan bahwa hadits riwayat Imam Ahmad No. 18945 ini maqbul sebagai bentuk pemeliharaan imunitas dengan dilarangnya begadang. Penelitian ini diharapkan memberikan manfa'at bagi informasi khalayak dan dapat memberikan pencerahan terhadap masyarakat akan bahayanya aktivitas begadang serta pentingnya menjaga pola hidup sehat agar imunitas dapat tetap terjaga terutama di tengah pandemi Covid-19. Penelitian ini memiliki keterbatasan yakni kurangnya penguasaan terhadap ilmu hadits maupun ilmu medis. Sehingga diperlukan penelitian lebih lanjut, terutama dari segi takhrij. Penelitian ini merekomendasikan agar adanya kolaborasi penelitian lebih lanjut antara peminat ilmu hadits dan ahli medis untuk meneliti terkait begadang dari segi hal apa yang harus dipersiapkan jika akan begadang dalam rangka hal yang urgen dan positif. 
Jurnal Riset Agama, Volume 1, Nomor 1 (April 2021): 71-82

Nurip Almunawir/Larangan Begadang sebagai Pemeliharaan Imunitas Perspektif Islam

\section{Daftar Pustaka}

Adzani, F. (2021). 11 Cara Menghilangkan Kebiasaan Begadang agar Cepat Tidur Nyenyak. Sehatq.

Al-'Asqalani, al-H. A. bin 'Ali bin H. (2005). Fathul Bari: Syarah Shahih alBukhari. Dar Thaybah.

Anshori, M. (2016). Kajian Ketersambungan Sanad (Ittisal al-Sanad). Jurnal Living Hadis, 1(2).

Arieselia, Z., Tasia, Y., \& Sasmita, P. K. (2014). Pengaruh Kurangnya Jumlah Jam Tidur terhadap Perubahan Kadar Gula Darah Pada Mahasiswa Preklinik Fakultas Kedokteran Unika Atma Jaya. 13(2), 128-136.

Darmalaksana, W. (2018). Paradigma Pemikiran Hadits. JAQFI: Jurnal Aqidah Filsafat UIN SGD Bandung, 2(1).

Darmalaksana, W. (2020a). Formula Penelitian Pengalaman Kelas Menulis. Kelas Menulis UIN Sunan Gunung Djati Bandung, 1-8.

Darmalaksana, W. (2020b). Metode Penelitian Kualitatif Studi Pustaka dan Studi Lapangan. Pre-Print Digital Library UIN Sunan Gunung Djati Bandung, 1-6.

Darmalaksana, W. (2020c). Penelitian Hadis Metode Syarah Pendekatan Kontemporer: Sebuah Panduan Skripsi, Tesis, dan Disertasi. Diroyah: Jurnal Studi Ilmu Hadits, 5, 58-68.

Darmalaksana, W. (2020d). Prosiding Proses Bisnis Validitas Hadis untuk Perancangan Aplikasi Metode Tahrij. Jurnal Ushuluddin UIN Sunan Gunung Djati Bandung, 1-7.

Darmalaksana, W. (2021a). Herbal Tumbuhan Senna dalam Pengobatan Infeksi Covid-19: Studi Takhrij dan Syarah Hadis. Pre-Print Kelas Menulis UIN Sunan Gunung Djati Bandung, 1-11.

Darmalaksana, W. (2021b). Kosmetik Halal sebagai Lifestyle untuk Kesehatan: Studi Takhrij dan Syarah Hadis.

Darmalaksana, W., \& Qomaruzzaman, B. (2020). Teologi Terapan dalam Islam : Sebuah Syarah Hadis dengan Pendekatan High Order Thinking Skill. Khazanah Theologia, 2(3), 119-131. https:/ / doi.org/10.15575/kt.v2i3.10083

Devi, A. D. (2020). Studi Kritik Matan Hadits. Al-Dzikra: Jurnal Studi Ilmu Al-Quran Dan Al-Hadits, 14(2).

Eliasson, A. H., Lettieri, C. J., \& Eliasson, A. H. (2010). Early to bed, early to rise! Sleep habits and academic performance in college students. Sleep Breath, 14, 71-75. https:// doi.org/10.1007/ s11325-009-0282-2

Fuad, S. (2020). Ahkam al-Khams dalam Dinamika Pemikiran Hukum Islam dan Perubahan Sosial. Tajdid, 4(1), 16-28.

Herwanto, \& Umboh, A. (2017). Penurunan Kapasitas Memori Kerja Pada Residen Pediatri Yang Kurang Tidur. Jurnal Muara Sains, Teknologi, Kedokteran, Dan Ilmu Kesehatan, 1(2), 62-67. https://journal.untar.ac.id/index.php/jmistki/article/view/887 
Jurnal Riset Agama, Volume 1, Nomor 1 (April 2021): 71-82

Nurip Almunawir/Larangan Begadang sebagai Pemeliharaan Imunitas Perspektif Islam

Kuntoro, A. T. (2018). Perancangan Informasi Begadang Bagi Kesehatan Tubuh Melalui Media Game Android. Universitas Komputer Indonesia.

Mustofa, A., \& Suhartatik, N. (2020). Meningkatkan Imunitas Tubuh dalam Menghadapi Pandemi Covid-19 di Karangtaruna Kedunggupit, Sidoharjo, Wonogiri, Jawa Tengah. Selaparang, Jurnal Pengabdian Masyarakat Berkemajuan, 4, 324-332.

Nadhiran, H. (2014). KRITIK SANAD HADIS: Telaâah Metodologis. Jurnal Ilmu Agama: Mengkaji Doktrin, Pemikiran, Dan Fenomena Agama, 15(1).

Purnama, M. D. W. (2021). Negative Impact of Staying Up Late for Health. Jurnal Studi Keperawatan, 2(1). https://ejournal.poltekkessmg.ac.id/ojs/index.php/J-SiKep/article/view/6801

Rahmawati, F., Jaji, \& Rizona, F. (2021). Pengaruh Sleep Hygiene terhadap Kualitas Tidur Penderitas Diabetes Mellitus Tipe 2. Jurnal Keperawatan 'Aisyiyah, 8(1).

Reza, R. R., Berawi, K., Karima, N., \& Budiarto, A. (2019). Fungsi Tidur dalam Manajemen Kesehatan. 8, 247-253.

Ridwan, M., Umar, M. H., \& Ghafar, A. (2021). Sumber-Sumber Hukum Islam dan Implementasinya (Kajian Deskriptif Kualitatif tentang AlQuran, Sunnah, dan Ijma'). Borneo: Journal of Islamic Studies, 1(2), 28-41.

Saltanera. (2015). Ensiklopedia Hadits 9 Imam. In Lembaga Ilmu Dan Dakwah Publikasi Sarana Keagamaan, Lidwa Pusaka.

Sulistiyani, C. (2012). Beberapa Faktor yang berhubungan dengan Kualitas Tidur pada Mahasiswa. Jurnal Kesehatan Masyarakat, 1(2).

Sumarmi, S. (2020). Kerja Harmoni Zat Gizi dalam Meningkatkan Imunitas Tubuh Terhadap Covid-19: Mini Review. IAIGIKMI, Universitas Airlangga, 250-256. https:// doi.org/10.2473/amnt.v4i3.2020

Yogis, N., Putra, P., Tania, M., \& Iklima, N. (2017). Perancangan Infografis Tentang Dampak Kebiasaan Begadang Terhadap Pola Tidur Sehat Bagi Remaja. 4(2), 53-60. 